\title{
Detection of the Change in the Morphology of the Courses of the River Ganga Using Satellite-derived Data: A Case Study Area
}

\author{
${ }^{* 1}$ Mukesh Kumar and ${ }^{2}$ Prof. A. R. Siddiqui \\ ${ }^{1}$ Research Scholar, Department of Geography, University of Allahabad, Prayagraj, India \\ 2Professor and Head, Department of Geography, University of Allahabad, Prayagraj, India
}

\begin{abstract}
This study seeks to examine the detection of course change in one of the major rivers of India, that is the Ganga, between the period of 1980 to 2020 and utilizes satellite driven data to demonstrate the visibility of shifting in its course. The purpose of study area is to find out the change detection of the river course. The channel shifting of the river course has been used to demonstrate the historical change in Landsat MSS, TM, ETM, and OLI/TIRS satellite images in the decades of 1980, 1990, 2000, 2010 and 2020. The study exhibits several reasons responsible for and lead to this shift, such as erosion problems and changing characteristics of the Ganga from Rampurghat to Chunar at different cross-section site points. This research area has been divided into six cross-sections, namely, XS-1, XS-2, XS-3, XS-4, XS-5, and $X S-6$. We attempt to examine how the river's shape and position have witnessed a change during the 1980-2020 period via using remote sensing and GIS methods. We have identified that the course line of the Ganga bas demonstrate a shift via using five types of satellite imagery in the above-mentioned period. The process of channel shifting has included an erosional and a depositional development occurred due to infrastructure damage by sedimentation, flood and changing river course. The Ganga course has shifted towards the south and the north direction places which as a result leads to village erosion. The major aspects of this study have a direct interaction with the physical and socio-cultural environment from upstream to downstream in crosssection. The course change detection of the study has been taken in the context of the river management and planning for future prevention of agricultural land, kuccha houses, food, and economic loss to farmers.
\end{abstract}

Keywords: The Ganga River Basin, Change Detection, River Morphology, Landsat Imagery, Cross-section, Channel Width, River Course Bank Line, Channel Landform, Erosion and Deposition

\section{Article Publication}

Published Online: 15-Dec-2021

*Author's Correspondence

8 Mukesh Kumar

9 Research Scholar, Department of Geography, University of Allahabad, Prayagraj, India

$\triangle$ mukesh.soram@gmail.com

C 2021The Authors. Published by RESEARCH REVIEW International Journal of Multidisciplinary. This is an open access article under the CC BY-

\section{NC-ND license}

(https://creativecommons.org/licenses/ by-nc-nd/4.0/)

\section{Introduction}

The Ganga is popularly known as the holy river. It is the second largest river in the Indian subcontinent covers several states in India. The Ganga valley also covers the major part of Uttar Pradesh. This sacred river originates from the Gangotri glacier, which is about 4,500 $\mathrm{m}$ above mean sea level in the Uttarakhand Himalayas and flows down towards the Bay-of-Bengal covers a distance of $2,525 \mathrm{~km}$. Every year the river faces the problems of sedimentary load millions of tons in the plain areas. The sedimentation problem in the Ganga is a natural phenomenon that takes place and affects several areas.

The sediment deposition creates severeral problems like the decrease of river depth due to riverbed siltation. But, when the discharge increases, the river exerts pressure on its two walls, and lateral erosion starts, which becomes the root of many flood and riverbank erosion hazards in India. ${ }^{1}$ The changes occured in river channels such as channel erosion, lateral erosion, vertical erosion, and bank erosion are natural processes of the river valley. Spatial and temporal changes, pollution, and sediment and study elements channel morphology is a major problem in the present time and is very important for this region. Channel morphology developed from processes involving sediment and water movement, channel migration, flood-plain, erosion and deposition, and wood entrainment and deposition. The morphology of alluvial channels has attracted the attention of researchers since early this century. ${ }^{2}$ 
The study seeks to examine the detection of change in the context of geographical and agricultural land that course change detection has been found by comparing Satellite-derived data during the periods of $1980-2020$. The detection of change in the river course is a study that is reinforced by the application of the RS, and the GIS methods. These two methods, Remote sensing and GIS are broadly used for the detection and monitoring of fluctuations in the physical environment. In this paper, we will utilize the RS and the GIS techniques to detect the changes in the Ganga course near Mirzapur city, India.

\section{The Study Area}

In this study, Bhadohi and Mirzapur districts are taken as the study area from Rampur Ghat to Chunar. It has represented about $60 \mathrm{~km}$ and is located within latitudes of $25^{\circ} 1^{\prime} \mathrm{N}$ to $25^{\circ} 07^{\prime} \mathrm{N}$ and longitudes of $82^{\circ} 25^{\prime} \mathrm{E}$ to $82^{\circ}$ 52 ' E. The physical background of study is shown in Fig. 1. The less work has been done and researched poorly on this subject. Moreover, the Ganga flows from west to east (from source to mouth) and its all stream and their canal of the basin take their sources over the Kaimur plateau and from the southern sides of the Vindhya range. The study region is flowed to slopes gradually northward from the Kaimur range to the Rewa Scarps and plain areas.

Geologically, Mirzapur district is comprized of two major geological formations, the Upper Vindhyan groups and the Lower Vindhyan groups, but in the Ganga river basin, only Upper Vindhyan groups have covered the major portion of the study regions and the Archaeans were involved granites, gneisses and alluvium. The Ganga valley has been taken in the context of topographical maps, CARTOSAT satellite image included with the GIS techniques. The areal photography has shown the extended shape of the Ganga valley and moderated to a steeper ground slope. This study can be applied for changing the river course in the river morphology, as well as disaster prevention from a similar type of Ganga basins. ${ }^{3}$ The Course Change Detection in river morphology has shifted in river channels such as bank erosion, lateral erosion, vertical erosion and deposition landform. The shifting course bank line has increased to the natural processes of the Ganga river valley. Regional developments such as sand mining, infrastructure construction on the riverbanks, artificial/ natural cut-offs, river embankment and breach, reservoir construction, and land use pattern have changed the natural geomorphologic dynamics of rivers. ${ }^{4}$

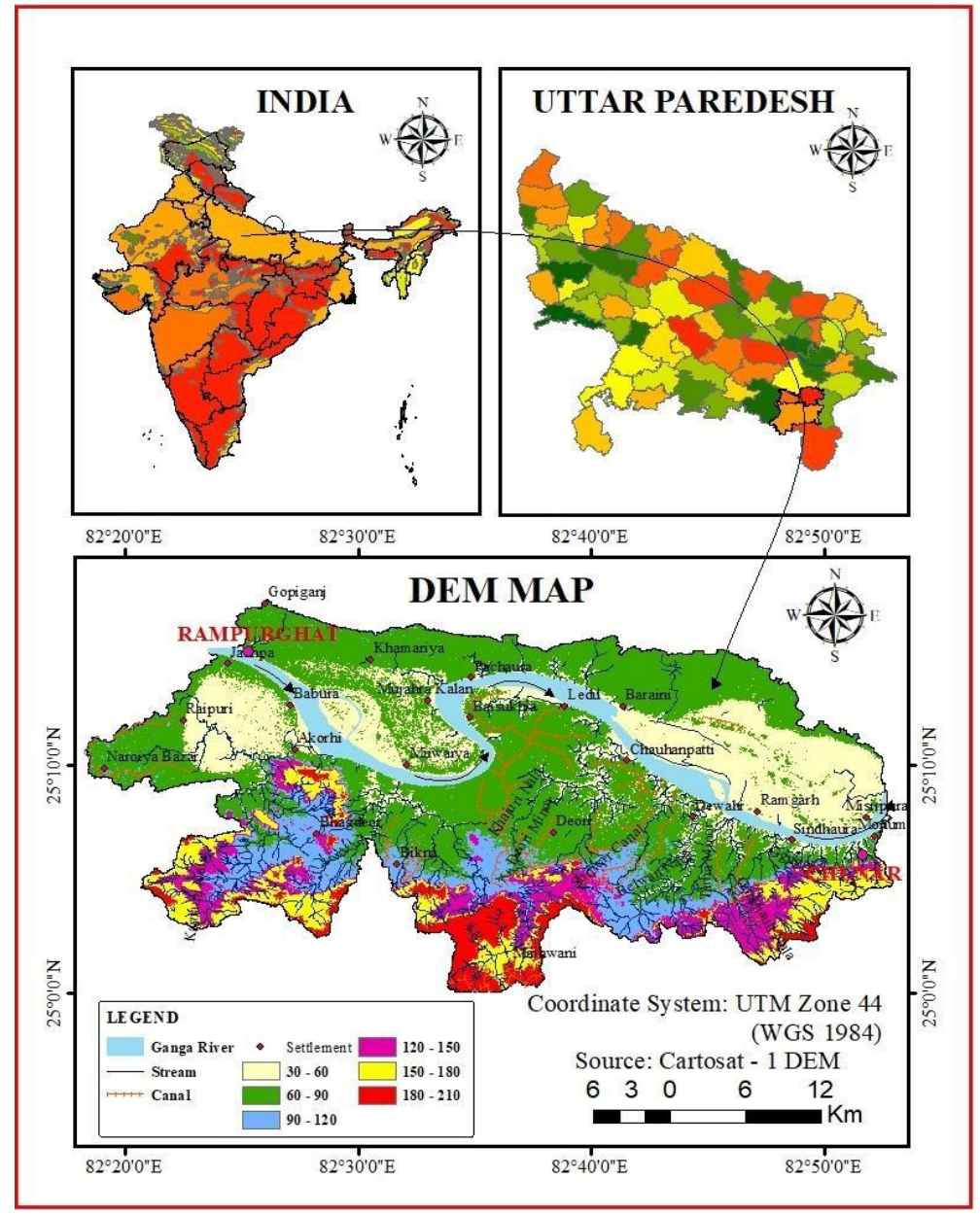

Fig. 1. Location map of the study region. 


\section{Database and Research Methodology}

The boundary of Ganga river has been shown in Landsat imagery (MSS, TM-C1, ETM, TM-C2, OLI/TIRS) and analyses the topographies of the old bank line of the Ganga in contrast with a very long time (from 1980 to 2020) in the study area. The topographical map of the study region has been taken from the Survey of India. Landsat MSS, Landsat TM, Landsat ETM, \& Landsat OLI/TIRS have been downloaded from the website http://usgs.gov during the dry period to find out multi-temporal and spatial satellite imagery. All the topographical maps and satellite images were mosaiced and georeferenced with the help of ArcGIS version 10.7. After georeferencing of the toposheets, they are rectified and resampled into a Universal Transverse Mercator (UTM) projection WGS 1984, Zone 44 North. The study region is verified with the global positioning system to elevation and other characteristics during the field survey. The whole streams of the Ganga river were extracted by digitizing with the help of the ArcGIS 10.7 environment using the ArcGIS Spatial Analyst extension and Arc hydro tool, available at bttp://earthexlorer.usgs.gov which is developed by USGS/NASA. The study region in the Ganga river valley has shifted due to physical background. After deciding on the study area in the different digital sources, that is needed to collect data in this fieldwork. All Landsat imageries to Remote sensing have been in change detection in the Ganges river basin integrated with GIS. For the purpose of computing and analysis of morphological characteristics of river basin geometrical method and techniques are used.

According to the study, this area intends to identify the shifting pattern of the Ganga River courses. These are operated after the changes and consequences of the spatial and temporal changes. This software analyses image enhancement, mosaic, re-sample, and re-projection in ArcGIS 10.7 software. That said, the shifting of Ganga river in the Landsat imageries have been used in the software ArcGIS 10.7 and Microsoft Excel 2016 likes georeferencing, digitizing, projection area, calculate geometry, and layout maps etc. The channel morphology of the study is an imaginable the research data, according to Remote sensing data like satellite imagery, digital satellite data, during the process, the increase/decrease of length of the River could be determined as well the lateral shift of the River was determined of the watersheds. ${ }^{5}$

Table no: - 1 The Landsat Imagery and Metadata of the Study Region.

\begin{tabular}{|c|c|c|c|c|c|}
\hline $\begin{array}{c}\text { Satellite } \\
\text { sensor }\end{array}$ & Year & Date & $\begin{array}{c}\text { Path } \\
\text { Row }\end{array}$ & Data Type & Map Projection \\
\hline MSS & 1980 & Feb 8, 1980 & $\begin{array}{c}153 / 43 \\
153 / 42\end{array}$ & MSS C1 & WGS_1984_UTM_Zone_44N \\
\hline TM & 1990 & Jan 10, 1990 & $142 / 43$ & TM C1 & WGS_1984_UTM_Zone_44N \\
\hline ETM & 2000 & Feb 15, 2000 & $142 / 43$ & ETM+C1 & WGS_1984_UTM_Zone_44N \\
\hline TM & 2010 & Feb 2, 2010 & $142 / 43$ & TM C2 & WGS_1984_UTM_Zone_44N \\
\hline OLI/TIRS & 2020 & Jan 13, 2020 & $142 / 43$ & OLI/TIRS C2 & WGS_1984_UTM_Zone_44N \\
\hline
\end{tabular}

(Source: USGS- Earth Explorer, 2020)

The Ganga river is one of the most eroded river found during the study in Uttar Pradesh. Naturally, this river channel has shifted the river bank line to the thalweg valley of the study region from south position to north position. The monitoring of Landsat imagery for the period of 1980, 1990, 2000, 2010, and 2020 has been utilized to compare the river channel shifting from Rampurghat to Chunar at different cross-section points. The river width of the course bank line has been divided into six cross-sections like XS-1, XS-2, XS-3, XS-4, XS-5, and XS6.6

\section{Result and Discussion}

This research deals with the shifting of the Ganga River Course where shifting in the course is identified and mapped via Landsat imagery data from USGS (Earth-Explorer, 2020) maps. With the help of the multitemporal satellite imagery the courses of different times were collected and processed in satellite image processing software like ArcGIS 10.7, and the final output is compared with the previous and newest courses of the river and the amount of deviation from the old course is determined. In Figures - 2, 1980, 1990, 2000, 2010, \& 2020 alignment was overlaid and keeping reference line and the lateral deviation was determined, as well the reduction in length was determined. The Landsat imagery that identifies the banking line of the Ganga river basin have demonstrated with using digital data and satellite imagery from Landsat MSS, TM and ETM OLI/TIRS suitable for land-water interfaces separation for research area and the study area is used 5 types of Landsat data in different data. 


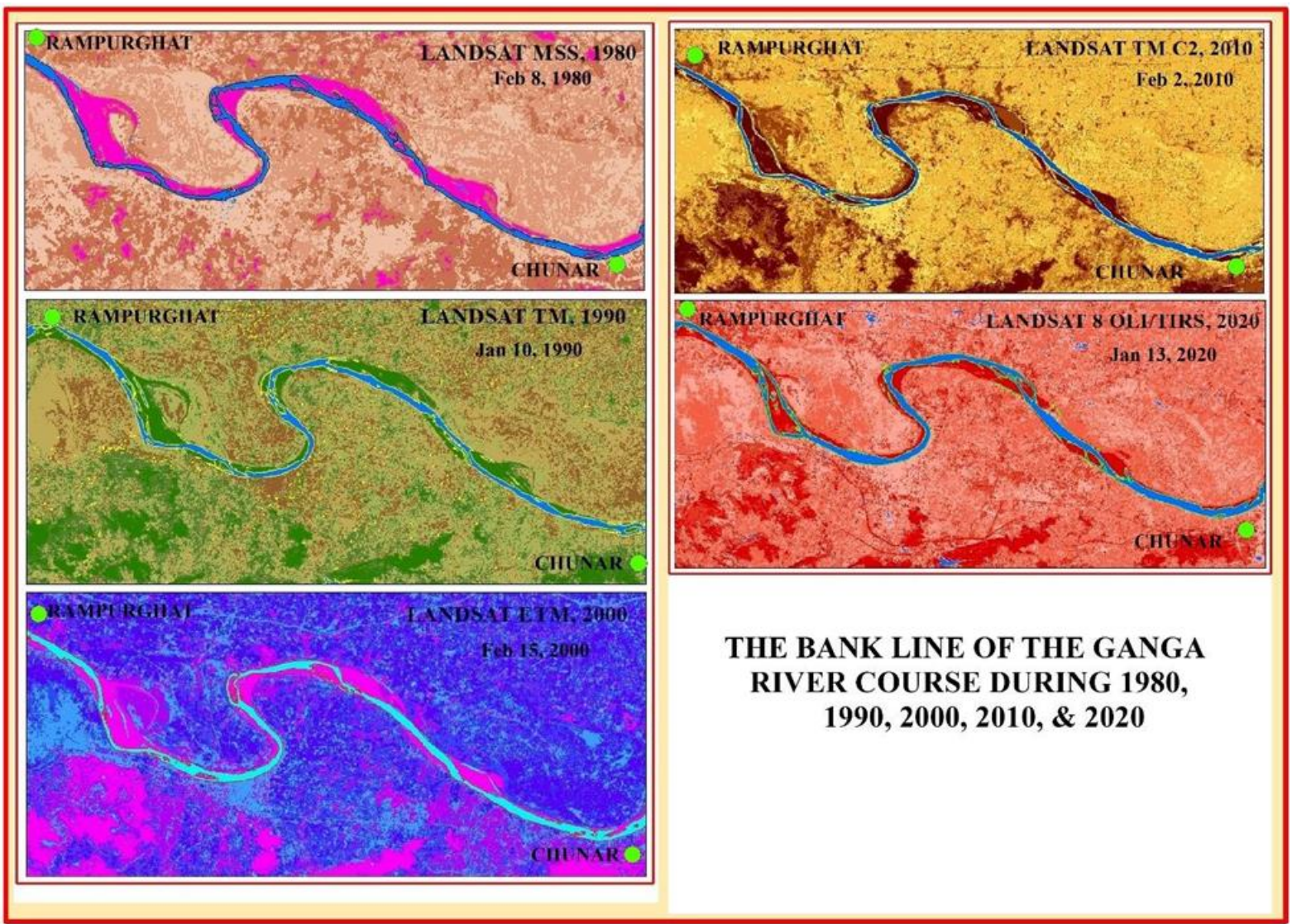

Figure: - 2 Delineation of Bankline of the Ganges River Course: Land-Water from 1980, 1990, 2000, 2010, and 2020.

\subsection{River course shifting from 1980 to 2020}

Scholars such as Gupta (2012) describes the dynamic nature of physical process of rivers including water quality, sediment, discharge, and river velocity in the natural process resutled due to gravity and topography. An apparent positions of the Ganga in five-time and river width the different cross-sections of calculating bank-line migration including "migrate" and permission losing energy to river velocity of the study area. The channel shifting includes bank erosion and deposition in the migration process. The Channel Migration Zone (CMZ) is a river channel is referred. particularly, The Ganga river basin is described by change detection of the study region on historical periods, before the situation goes into the Bay of Bengal. ${ }^{7}$

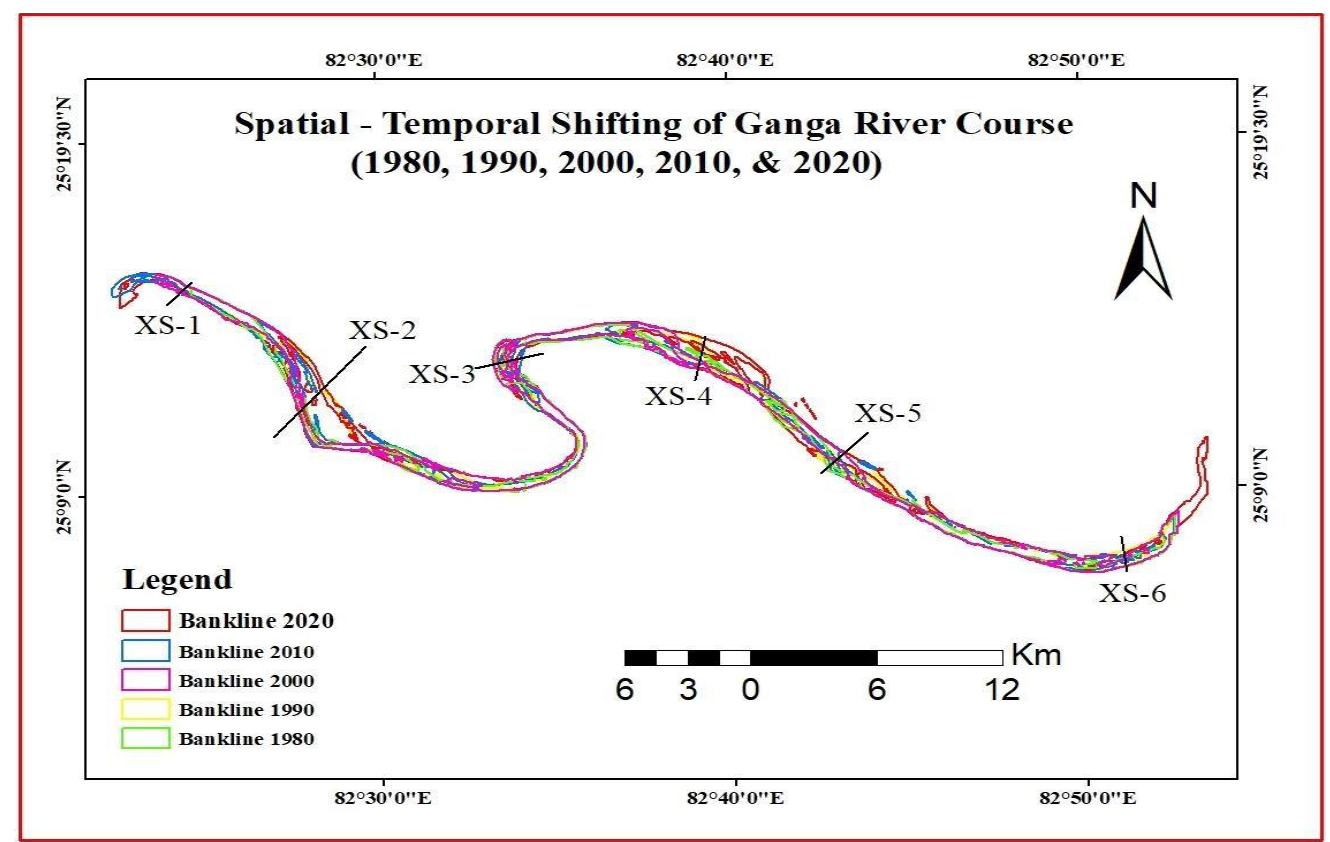

Figure: 3 Apparent Positions of the Ganga river in five-time and river width the different crosssections of calculating bankline migration $(1980,1990,2000,2010, \& 2020)$. 
Milliman and Meade (1983) examines the three major rivers, the Ganga, the Brahmaputra, and the Indus. Hasnain and Thayyen (1999) are the most sediment basin in the world. ${ }^{8}$ At the onset, the River channel shifting has been mainly dependent on hydrological and morphological features and seen its affect on such as water quality, discharge, sediment load, river velocity, erosion, and deposition. The Ganga is a meandering river to the lateral erosion occurs and causes river bank shifting line. The Landsat Satellite imagery has been defined via Landsat MSS data of 1980, Landsat TM data of 1990, Landsat ETM, 2000, Landsat TM, 2010 and Landsat OLI/TIRS. The study region has been depicted to generate digital images of the various periods and analysed the channel shifting nature of the Ganga river valley. In addition, it finds that the Ganga has gradually shifted its course and caused of land loss from northeast to southeast direction. This can be seen during the period of $1980-2020$ at the cross-section XS - 4 in right bank and left bank in maximum shifted. It was $1.28 \mathrm{~km}$ in 1990 and in 2000 the river course shifted to $1.07 \mathrm{~km}$ of the cross-section XS -4 in the right bank. Gupta (2012) has demonstrated a sediment load of 300-500 million tonnes years. The Ganga basin has described as of how $1.4 \mathrm{~km}$ to $2 \mathrm{~km}$ wide the smallest amount points in the study area and it has varied from $10 \mathrm{~km}$ to $13 \mathrm{~km}$ wide in this broadest sections. The study region of the course change detection in river morphology is available about $0.7 \mathrm{~km}$ to $1.5 \mathrm{~km}$ wide and that has been defined from time to time as a large in the channel bars. The many channel pattern of the river morphology has been meandering with an anabranching channel pattern. ${ }^{9}$

\subsection{Shifting Pattern of The Ganga River Course From 1980 To 1990}

The shifting of the Ganga river from 1980 to 1990 has been taken into six cross-sections that denote the river course continuously changing its plan form through the shifting river course line. Here, it describes in the field area the erosion and deposition activities at the different crosssections. From figure 4, it is clear that the river bank line is not like the same cross-section. Spatial and temporal change of the Ganga river changed in every crosssection to the Ganga river. The cross-section XS - 1in 1980 is wide more than 1990. The growth of left river course line in 1990 is added. Cross-section XS - 2 the river course line 1980 was downside than 1990. In crosssection XS - 2, the river course shifted to the left bank $(1.13 \mathrm{~km})$ and the right bank $(0.17 \mathrm{~km})$. At cross-section XS - 3 depositional works are stronger than erosion. The river shifted to the bank line in 1980 from right $(-0.10$ $\mathrm{km})$ to left side and the bank line 1980 from left to right $(-0.50 \mathrm{~km})$. From cross-section 4 to 5 shifting river channel to the northeast course. Cross-section XS - 4, is the most variable point. At this cross-section XS - 4 massive quantity erosion in the right bank $(-1.0 \mathrm{~km})$ and sedimentation in the left bank $(0.56 \mathrm{~km})$ of the channel morphology from 1980 to 1990 . From cross-section, 5 to 6 shifting river channel to the northeast course. Erosion followed added in the right bank and having occurred in the left bank (Fig. 4).

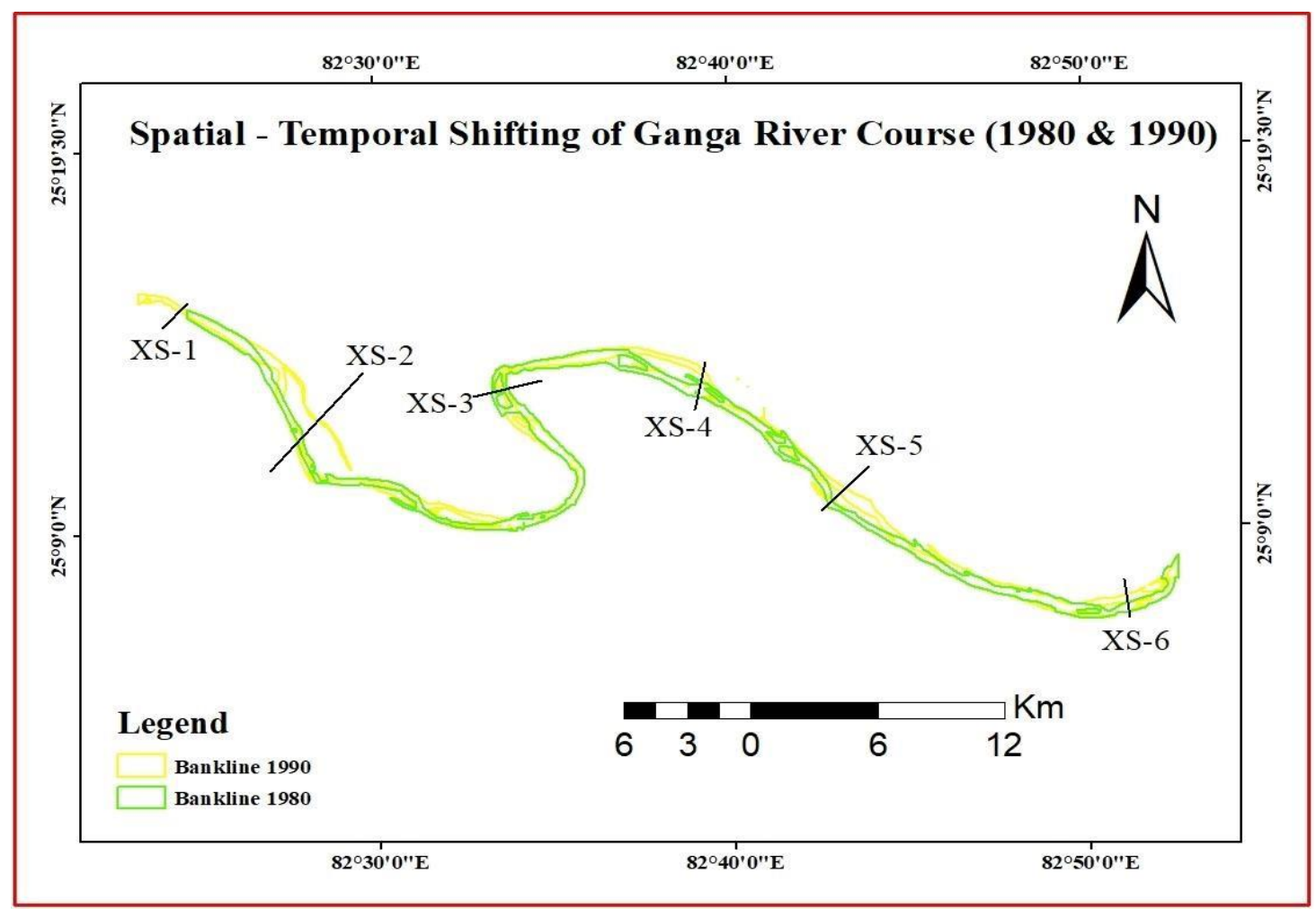

Figure 4: Apparent position of the River Ganga in two time periods and the cross-sections of calculating bank-line migration from 1980 to 1990. 
Table 2: Bank-line Migration Status along different Cross-Sections from 1980 to 1990.

\begin{tabular}{|c|c|c|c|c|}
\hline Cross-section & River width 1980 (km) & River width 1990 (km) & Right bank & Left bank \\
\hline $\mathrm{XS}-1$ & 0.50 & 0.32 & 0.16 & 0.10 \\
\hline $\mathrm{XS}-2$ & 0.60 & 1.70 & 0.17 & 1.13 \\
\hline $\mathrm{XS}-3$ & 0.84 & 0.30 & -0.10 & -0.50 \\
\hline $\mathrm{XS}-4$ & 0.90 & 0.40 & -1.0 & -0.56 \\
\hline $\mathrm{XS}-5$ & 0.36 & 0.37 & -0.85 & 0.90 \\
\hline $\mathrm{XS}-6$ & 0.50 & 0.90 & 0.20 & 0.40 \\
\hline
\end{tabular}

At the cross-section XS - 1, the value $0.50 \mathrm{~km}$ is the channel width and this has been $0.32 \mathrm{~km}$ approximately in 1980 and 1990. In 1980 and 1990 the value $0.60 \mathrm{~km}$ is the channel width and

$1.70 \mathrm{~km}$ at the cross-section XS - 2. 'Cross-section' XS - 3, the river channel width has been defined as $0.84 \mathrm{~km}$ and $0.30 \mathrm{~km}$ nearly in 1980 and 1990 . 'Cross-section' XS - 4, the 0.90 distance was river channel width and 0.40 $\mathrm{km}$ in well-ordered 1980 and 1990, in 'Cross-section' XS - 5 the river channel width has been defined $0.36 \mathrm{~km}$ and $0.37 \mathrm{~km}$ and so 'Cross-section' has been $0.50 \mathrm{~km}$ and $0.90 \mathrm{~km}$ almost in 1980 and 1990 (Table 2). In this place, the river is more extended in 1990. The bank line is witnessed a more shift in cross-section XS - 4. In this place, the river shifted to the left bank $(1.13 \mathrm{~km})$ and right bank $(-0.56 \mathrm{~km})$ from 1980 to 1990.

Cross-section width channel shifting of bank line from 1980 to 1990 describes that more river channel width in the cross-section XS - 1 and 5 the river channel width was a reduced amount of dissimilar values from 1980 to 1990. Cross-section XS - 2 describes the maximum variations in this figure 5. In 1990 the maximum deposited land is extra monitored this work field. Hence the channel width variation was slowly increased (Fig. 5).

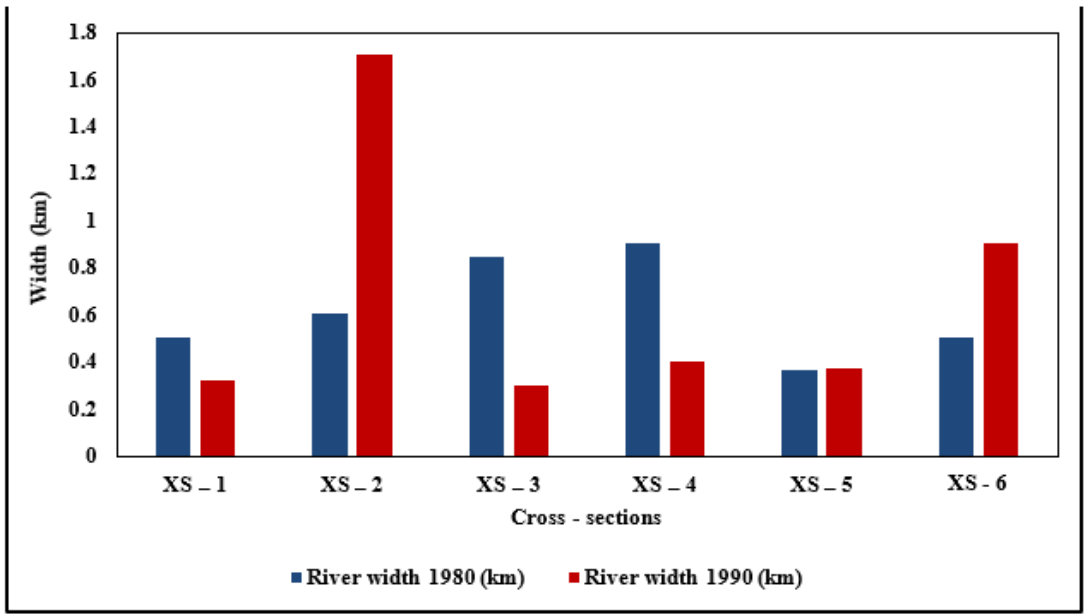

Figure 5: The Channel Width Variation from 1980 to 1990.

The river channel shifting line from 1980 to 1990 at the cross-section XS - 2 in the left bank that was $1.13 \mathrm{~km}$ in maximum depositional and erosional land cover and pattern. In the right bank, the maximum river channel shifting in cross-section XS - 5 but the channel width has migrated towards the left bank. It was $-0.85 \mathrm{~km}$ meter. In the study region of table 2, the river course shifted to more in the right bank from 1980 to 1990. Overall river course line migration to the northeast.

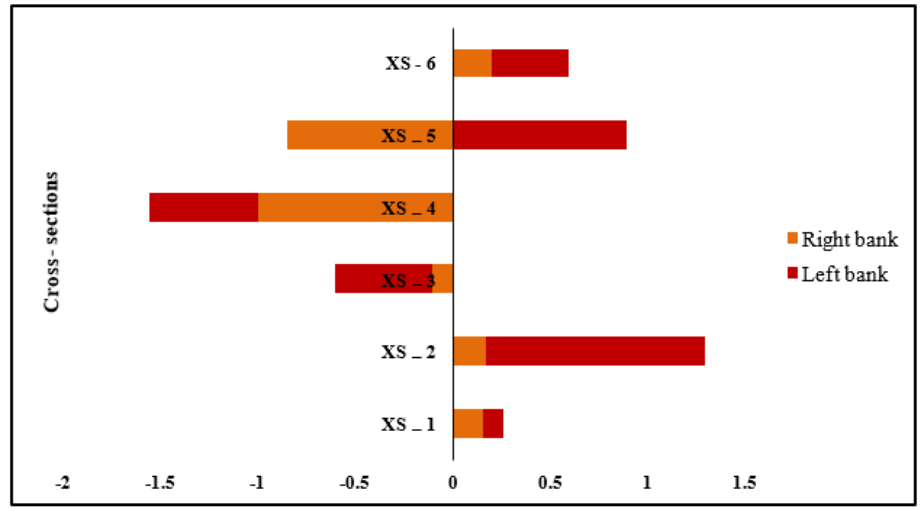

Figure 6: The River Course Shifting Line from 1980 to 1990. 
Based on river channel shifting mentione above and followed in cross-section XS - 2 and XS - 4. In crosssections, XS - 2 and XS - 4 channels shifted to the left and right direction that was $1.13 \mathrm{~km}$ and $-1.0 \mathrm{~km}$ (Fig. 6).

\subsection{Shifting Pattern of The Ganga River Course From 1990 To 2000}

The river channel bank lines shifted in different cross-sections from 1990 to 2000. A crosssection has represented the shape of the river, meandering, and shifting river channel in the research field. The river bank line is believed to show trends from one position to another bank line. The shifting of the bank line at the cross-section XS - 1, therefore, the deposition factor has demonstrated more till 2000. Further, the shifting pattern of the Ganga river course describes a small amount of erosional position in cross-section XS - 1 is shown in the right bank and depositional location that followed in the left bank (Fig. 7). Cross-section, XS - 2 the channel variation width decreased the causes of left bank deposition.

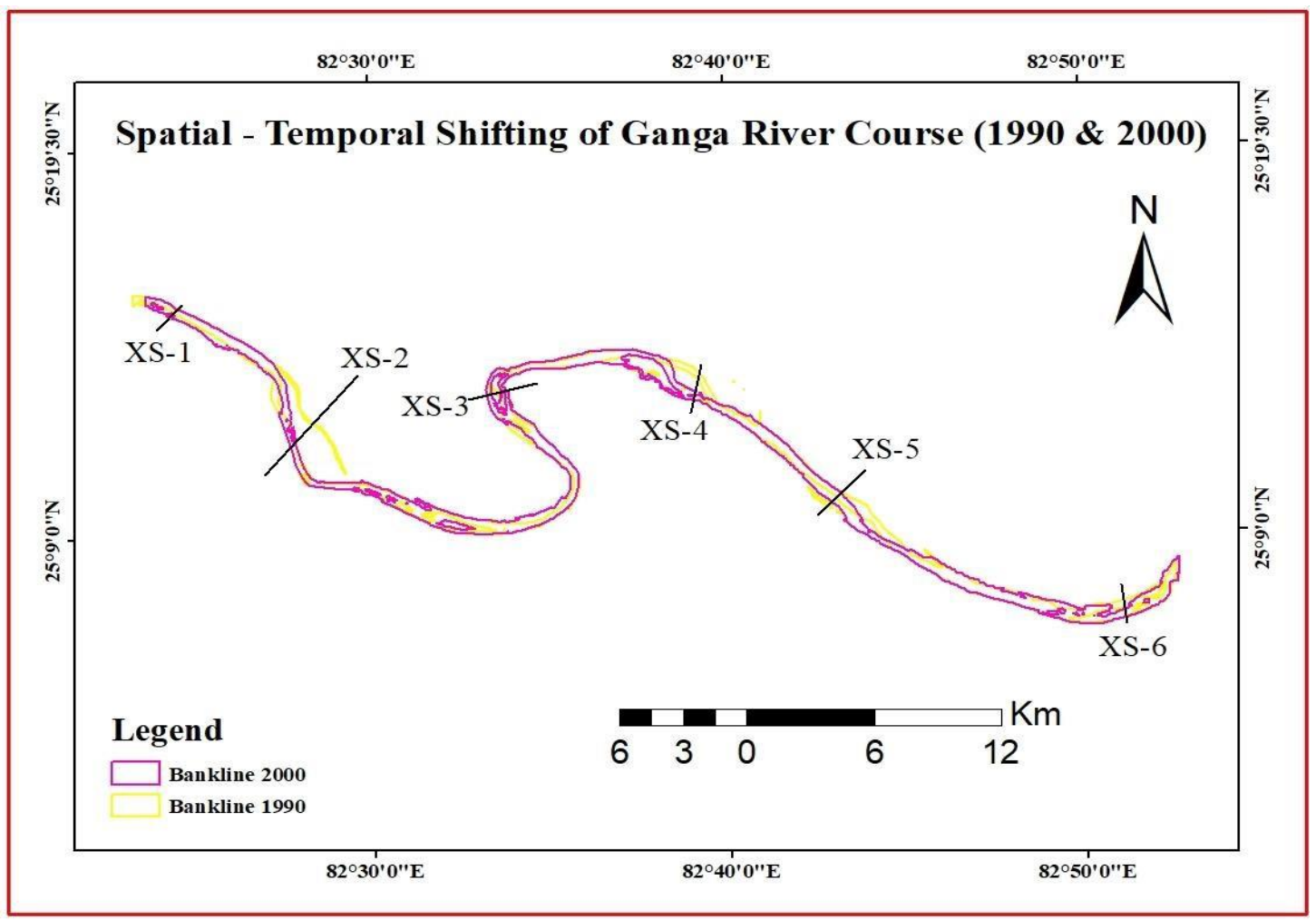

Figure 7: Apparent position of the River Ganga in the two-time zone and the cross-sections of calculating bank-line migration from 1990 to 2000.

Cross-section XS - 3 was a huge amount of channel shifted and resulted an erosional and depositional activities were very fast the causes of left bank deposition and active the right bank of erosional processes. A cross-section reveals that the river has migrated towards the left bank. In cross-section XS - 4, a huge amount of variation is also found which is deposition on the left bank $(0.53 \mathrm{~km})$, the river has migrated towards the right bank. Crosssection XS -5 has represented a large number of erosional sites in 2000. The deposit sediments have occurred more on the left bank of the Ganga River which has shifted to the right bank $(0.35 \mathrm{~km})$. and here the river has migrated towards the right bank. In the cross-section XS - 6, deposits more occur on the right bank of the river and the left bank $(-0.43 \mathrm{~km})$ has shifted towards the right bank $(0.17 \mathrm{~km})$.

Table 3: Bank-Line Migration Status along with the Cross-Sections from 1990 to 2000

\begin{tabular}{|c|c|c|c|c|}
\hline $\begin{array}{c}\text { Cross- } \\
\text { Section }\end{array}$ & River Width $1990(\mathrm{~km})$ & River Width 2000 (km) & Right Bank & Left Bank \\
\hline $\mathrm{XS}-1$ & 0.32 & 0.62 & 0.31 & 0.10 \\
\hline $\mathrm{XS}-2$ & 1.70 & 0.45 & 0.12 & 0.20 \\
\hline $\mathrm{XS}-3$ & 0.30 & 1.04 & 0.29 & 0.53 \\
\hline $\mathrm{XS}-4$ & 0.40 & 0.50 & 1.07 & -1.03 \\
\hline $\mathrm{XS}-5$ & 0.37 & 0.65 & 0.35 & -0.15 \\
\hline $\mathrm{XS}-6$ & 0.90 & 0.47 & 0.17 & -0.43 \\
\hline
\end{tabular}


The River channel width describes a spatial and temporal changes to the morphology of Ganga valley . The crosssection indicates the change of the channel width from 1990 to 2000. River width was increased in 2000 at crosssection XS - 1. During this time, the river channel width was $0.32 \mathrm{~km}$ in 1990 and subsequently later enlarged in 2000 was $0.62 \mathrm{~km}$. Cross-section XS - 2, the river channel size was reduced. Since that deposition process is represented in this study. The river channel width was around $1.7 \mathrm{~km}$ and $0.45 \mathrm{~km}$ distance in the respective period, 1990 and 2000. In cross-sections XS - 3, the channel width is increased because of the eroded right and left bank in comparison to the river width 1990. In this section, the river channel width was variation from 1990 to 2000 .

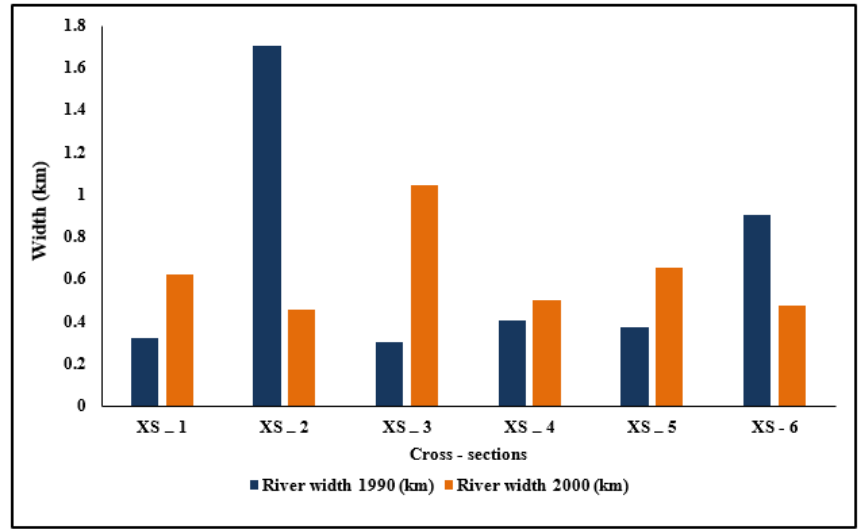

Figure 8: Channel Width Variation from 1990 to 2000.

Later on, the cross-sections XS - 4 was increased in the year 2000. This time river width was $0.40 \mathrm{~km}$ and 0.50 $\mathrm{km}$ approximately in 1990 and 2000, and in this section, the river has demonstrated a shifting trend towards the right bank because the right bank was rapidly eroded and bank line shifting having right side $(1.07 \mathrm{~km})$. In the cross-sections XS - 5 and XS - 6, the channel width was $0.37 \mathrm{~km}$ and $0.90 \mathrm{~km}$ but in 2000 the river width was increased by 0.65 and XS - 6, the channel width was having decreased to $0.47 \mathrm{~km}$ in 2000 . The bank line shifting of the area has shown a little amount of channel variation in the right bank $(0.35 \mathrm{~km})$. the channel reveals that the river is shifting the line towards the right bank (Fig. 8).

Furthermore, based on the cross-section the river channel bank line has been described as 'crosssection XS - 2'. In the cross-section XS -2 , the channels shifted to the left and right direction was $1.7 \mathrm{~km}$ and $0.45 \mathrm{~km}$ and having channel variation the areal spread of the river in squeezing and increasing. (Fig. 8).

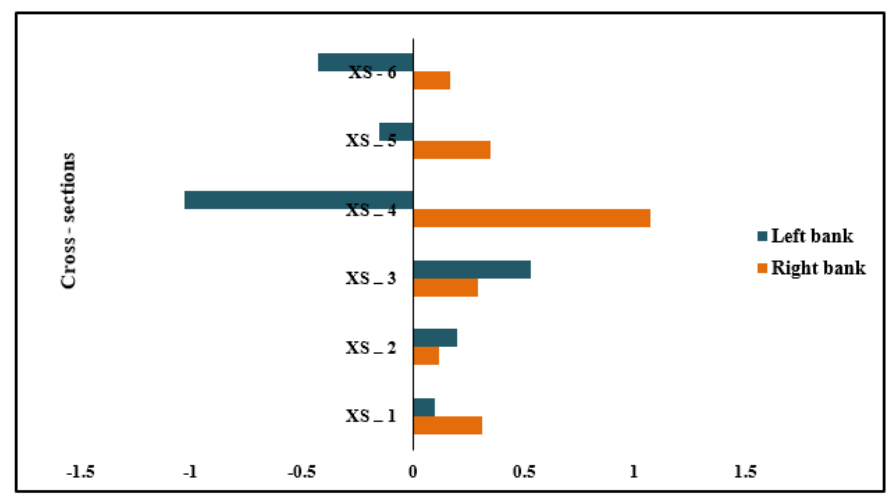

Figure 9: River Course Shifting line from 1980 to 1990.

As mentioned above, the bank line shifting of the area is measured through the cross-section method for acceptance phenomena of the river channel shifting view-site in the Ganga valley (fig. 9). Therefore, that river channel width has demonstrated the river bank line to gradually losing many channels landscape from Southwest to Northeast course.

\subsection{Shifting Pattern of the Ganga River Course from 2000 to 2010.}

The shifting trends of the Ganga from 2000 to 2010 and channel change are shown by the map (Fig. 10). The hydrological and morphological components and their characteristics are accountable for channel shifting. In the cross-section XS - 1, the bank line in 2010 demonstrated the change of the river course bank line to erosional position on the left bank line and depositional position on the right bank line. Here in 2000, the river channel 
width was more spread than in 2010. Moderately, in cross-section XS - 2, the river channel width was increased a large amount (from $0.45 \mathrm{~km}$ to $1.42 \mathrm{~km}$ increasing) in 2010 than in 2000 due to erosion and revealed that the areal spread of the river has increased, shifted bank line right and left bank. Comparatively, in cross-section XS - 3, the river channel width was increased from 2000 to 2010 (from $1.04 \mathrm{~km}$ to $1.14 \mathrm{~km}$ ) and in this section, the river is migrating towards the left bank $(0.50 \mathrm{~km})$.

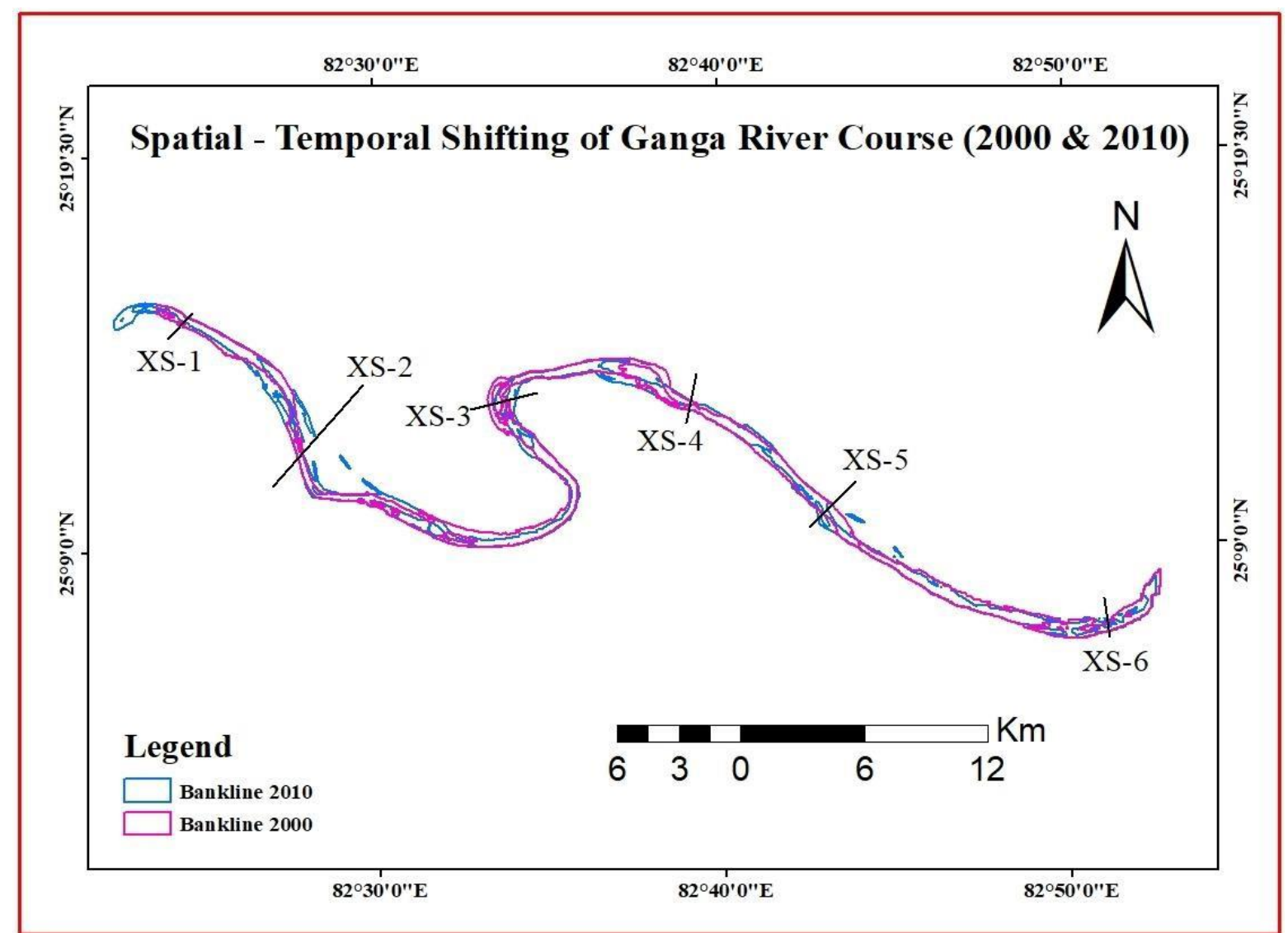

Figure 10: Apparent position of the River Ganga in the two-time zone and the cross-sections of calculating bank-line migration from 2000 to 2010.

The bank line has witnessed a change in a small amount in 2010 as shown in the cross-section XS - 4 than 2000. It is found that he channel width was wide due to erosion on both sides to increase the right bank $(0.10 \mathrm{~km})$ and the left bank $(0.20 \mathrm{~km})$, the cross-section XS - 5 in 2000, the river channel width was a small area. However, in 2010 the river channels width has been cleared wide-area cover to erosion process on the right bank line $(0.35$ $\mathrm{km})$.

Table 4: Bank-line Migration Status along with the Cross-Sections from 2000 to 2010

\begin{tabular}{|c|c|c|c|c|}
\hline $\begin{array}{c}\text { Cross- } \\
\text { Section }\end{array}$ & River Width 2000 (km) & River Width 2010 (km) & Right Bank & Left Bank \\
\hline $\mathrm{XS}-1$ & 0.62 & 0.35 & -0.30 & 0.10 \\
\hline $\mathrm{XS}-2$ & 0.45 & 1.42 & 0.12 & 0.20 \\
\hline $\mathrm{XS}-3$ & 1.04 & 1.14 & -0.40 & 0.50 \\
\hline $\mathrm{XS}-4$ & 0.50 & 0.55 & 0.10 & 0.20 \\
\hline $\mathrm{XS}-5$ & 0.65 & 1.00 & 0.35 & 0.10 \\
\hline $\mathrm{XS}-6$ & 0.47 & 0.70 & 0.10 & 0.25 \\
\hline
\end{tabular}

The river channel width has $0.65 \mathrm{~km}$ in 2000 and the shifting position has increased by $1.00 \mathrm{~km}$ distance in 2010 . 'Cross-section' XS - 5, the river is shifted gradually towards the right bank. In cross-section XS - 6 , the river width has increased a little area in 2010 that river width has $0.47 \mathrm{~km}$ and $0.70 \mathrm{~km}$ has available in 2000 (Table 4). 


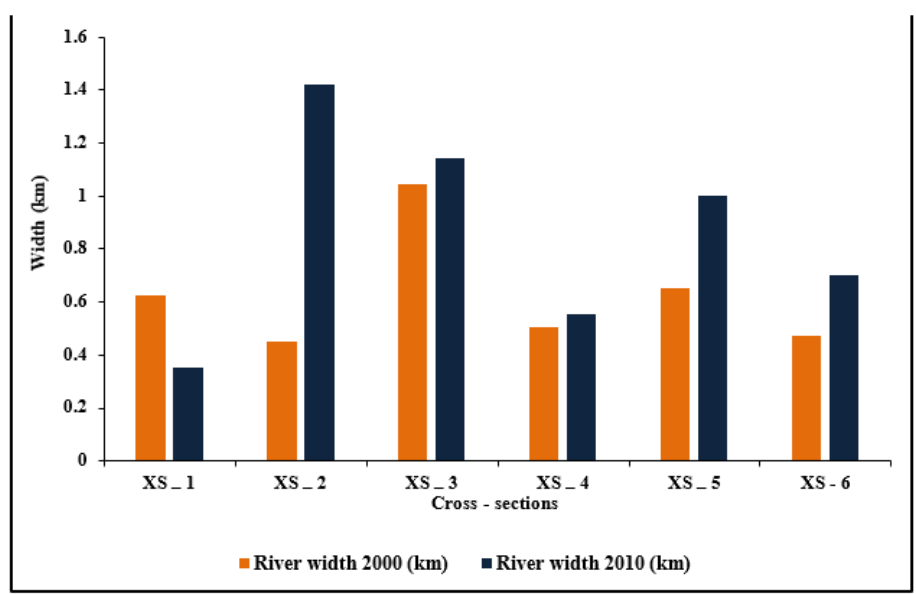

Figure 11: Channel Width Variation from 2000 to 2010.

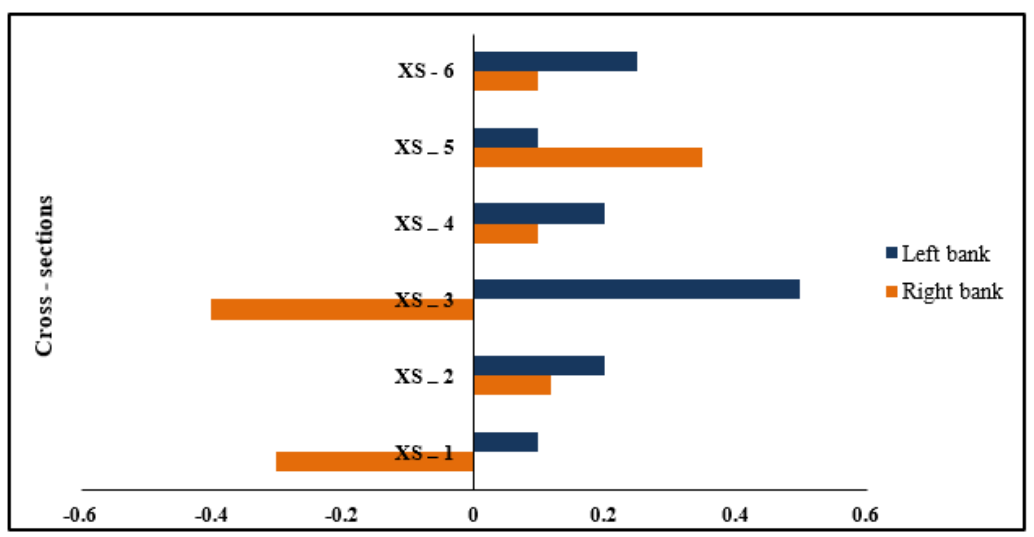

Figure 12: River Course Shifting line from 2000 to 2010

A cross-section XS - 2, the channel width has been defined as $0.45 \mathrm{~km}$ in 2000 and $1.42 \mathrm{~km}$ in 2010 . In this segment it is the maximum channel width of river. In cross-section XS - 3, the channel width has increased a little amount on the left bank and the right bank has migrated towards the left bank (from -0.40 to $0.50 \mathrm{~km}$ ). Here, the channel width was $1.04 \mathrm{~km}$ in 2000 , and in 2010 was $1.14 \mathrm{~km}$.

All the cross-sections drawn along the courses of the river are used to measure the bankline migration status. How the river has shifted along with these fixed 6 and the cross-sections has been depicted in Tables 4 . From the above map, it can be said that the river bank line has gradually losed by erosion factor and depositional factor land and water from south-west to north-east course. In this section, the shifting bank line of the river on both banks (left and right) from 2000 to 2010. That river channel width has rapidly shifted from the north-west to the northeast course. Finally, in the cross-sections XS - 1 \& XS -3 the river width increased in both banks by erosion, and here, the river is migrated towards the left bank.

\subsection{Shifting Pattern of The Ganga River Course From 2010 To 2020}

The detection of the river morphology has undergone a massive shift and migration of the bank line sites. The Ganga river has changed channel outline in response to morphological and hydrological characteristics in the temporal and spatial changes. The study region is limited to describe only one feature that can be noticed through the spatial and temporal changes (Fig. 13). The shifting river channel of the Ganga river demonstrated that the unavailable point has been improved into not the same direction and the different 'cross-sections' in this section. 


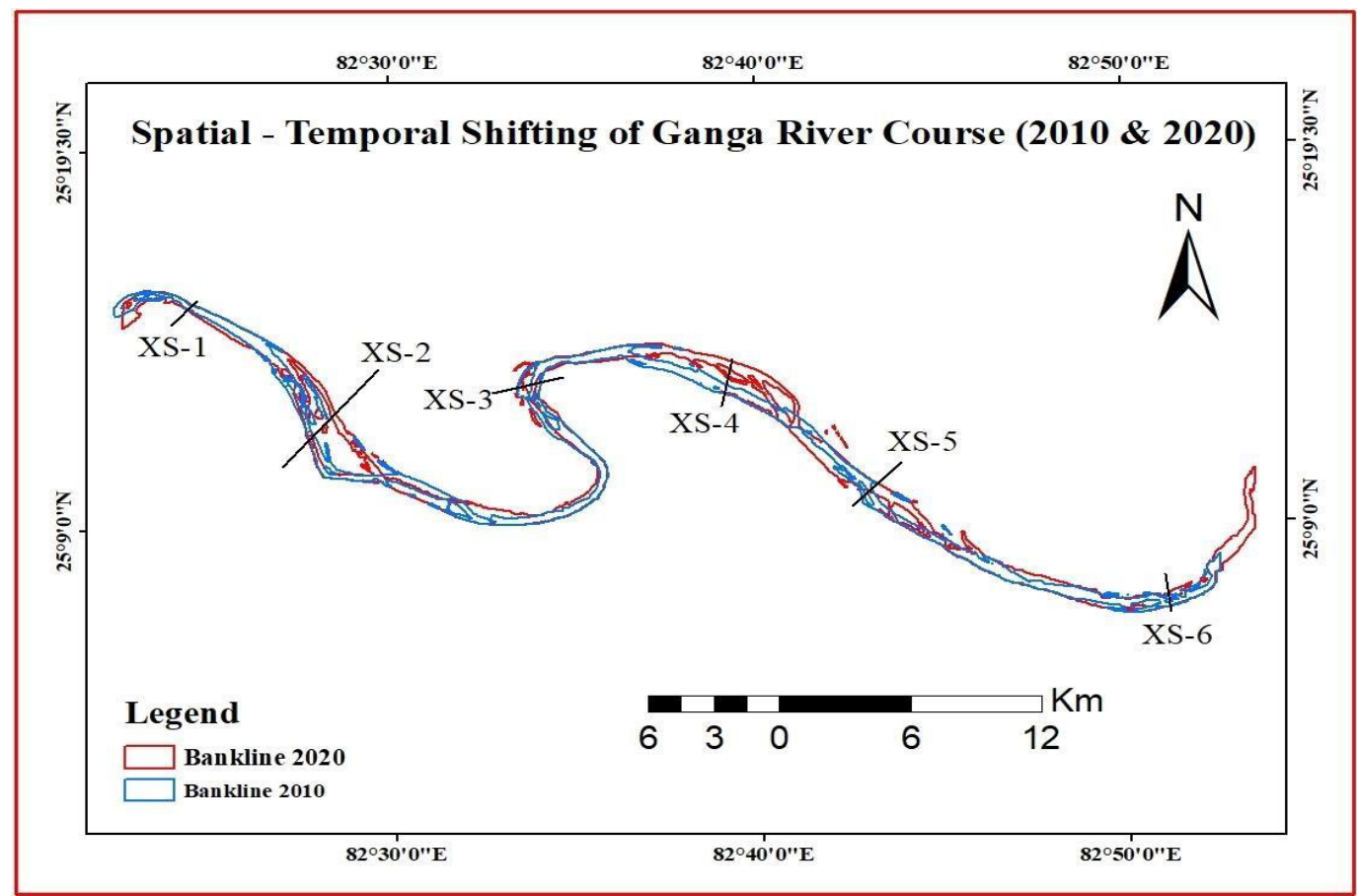

Figure 13: Apparent position of the River Ganga in the two-time zone and the cross-sections of calculating bank-line migration from 2010 to 2020

Because of changing nature of the channel width, the river channel width has been represented from 2010 to 2020. The river channel width has shown $0.35 \mathrm{~km}$ in the 2010 periods and $0.50 \mathrm{~km}$ in the 2020 periods at the 'cross-section' XS - 1. That river channel width has increased in 2020 than 2010. In the cross-section XS - 2 of the apparent position, the river channel width has been represented $1.42 \mathrm{~km}$ in 2010 and $2.05 \mathrm{~km}$ in 2020 that river channel width has been increased in 2020 than 2010. Again the river channel width has decreased in 2020 at the cross-section XS - 3. Here, the river channel width has been defined as $1.14 \mathrm{~km}$ in 2010 and $0.72 \mathrm{~km}$ distance in 2020. In the 'cross-section' XS - 4, the river channel width has been depicted as $0.55 \mathrm{~km}$ in 2010 and $0.95 \mathrm{~km}$ distance in 2020. That river channel width in change detection has been enlarged in 2020 than in 2010 (Table 5). In the cross-section XS -5, the river channel width has been depicted as $1.00 \mathrm{~km}$ in 2010 and $0.64 \mathrm{~km}$ distance in 2020. That river channel width has been reduced in 2020 than in 2010. Again this 'cross-section' XS - 6, the river channel width has been defined as $0.70 \mathrm{~km}$ and $0.81 \mathrm{~km}$ in 2020 . The river channel width has been increased in 2020 than in 2010.

Table 4: Bank-line Migration Status along different Cross-Sections from 2010 to 2020.

\begin{tabular}{|c|c|c|c|c|}
\hline Cross-section & River width 2010 (km) & River width 2020 (km) & Right bank & Left bank \\
\hline $\mathrm{XS}-1$ & 0.35 & 0.50 & 0.20 & 0.10 \\
\hline $\mathrm{XS}-2$ & 1.42 & 2.05 & 0.20 & 0.56 \\
\hline $\mathrm{XS}-3$ & 1.14 & 0.72 & -0.24 & -0.30 \\
\hline $\mathrm{XS}-4$ & 0.55 & 0.95 & -0.80 & 1.28 \\
\hline $\mathrm{XS}-5$ & 1.00 & 0.64 & -0.15 & 0.10 \\
\hline $\mathrm{XS}-6$ & 0.70 & 0.81 & 0.12 & 0.14 \\
\hline
\end{tabular}

The river course bank line of the 2010 periods has not witnessed a change in 2020 by a large amount of erosion on the left bank line and the river channel has been eroded in the right bank at cross-section XS - 1 (Fig. 13). In this section, the river has increased on both sides. In crosssection XS - 2, the right bank was eroded in 2020 in which the areal spread of the river had shifted the right bank and the left bank had also shifted in the same side. The bank line of the cross-section XS - 3, both sides of the bank were deposited sediment in which the areal spread of the river was squeezing. Here, the channel width was narrow because the river course line was shifted in the right bank $(-0.24 \mathrm{~km})$ and the left bank $(-0.32 \mathrm{~km})$ in 2010 and 2020 . The channel variation was changing from 2010 to 2020 due to erosion on the left bank and deposited the right bank at the cross-section XS - 4. Here, the river has migrated towards the left bank and the areal spread of the river is squeezing the right bank in 2020. The morphological and hydrological component was changing the nature of river pattern, its direction, and the bank line migrating has perceived (Fig. 13). In 2020 the river channel has also been a meandering pattern which has been presented in this section because of changing nature of the river channel. In cross-section XS - 5, the river 
width was moved from narrow to spread in 2020. Its width varied from 2010 to 2020 . The river channel width has been represented $1.00 \mathrm{~km}$ in 2010 and $0.64 \mathrm{~km}$ in 2020 . The river channel width has been decreased in 2020 than 2010. Here, the channel width has been migrating towards the left bank. 'Cross-section' XS -6 the river channel width has been depicted as $0.70 \mathrm{~km}$ in 2010 and $0.81 \mathrm{~km}$ in 2020. The river width has been increased in 2020 than 2010. Here, the river width was increased on both sides. Distance within the right and the left bank of the study area has occurred at the various cross-sections. The river channel width has been changed at cross-section XS -2 in the maximum channel width. The channel width has been decreased in 2020 at 'cross-section' XS - 3 and 5 than 2010. At the others, cross-section width has been increased in 2020 than 2010. Change detection of the river channel width has been shifted at all the 'cross-sections'. In this section, the river channel bank line has shifted north sides to the northeast course from 2010 to 2015 (Fig. 15).

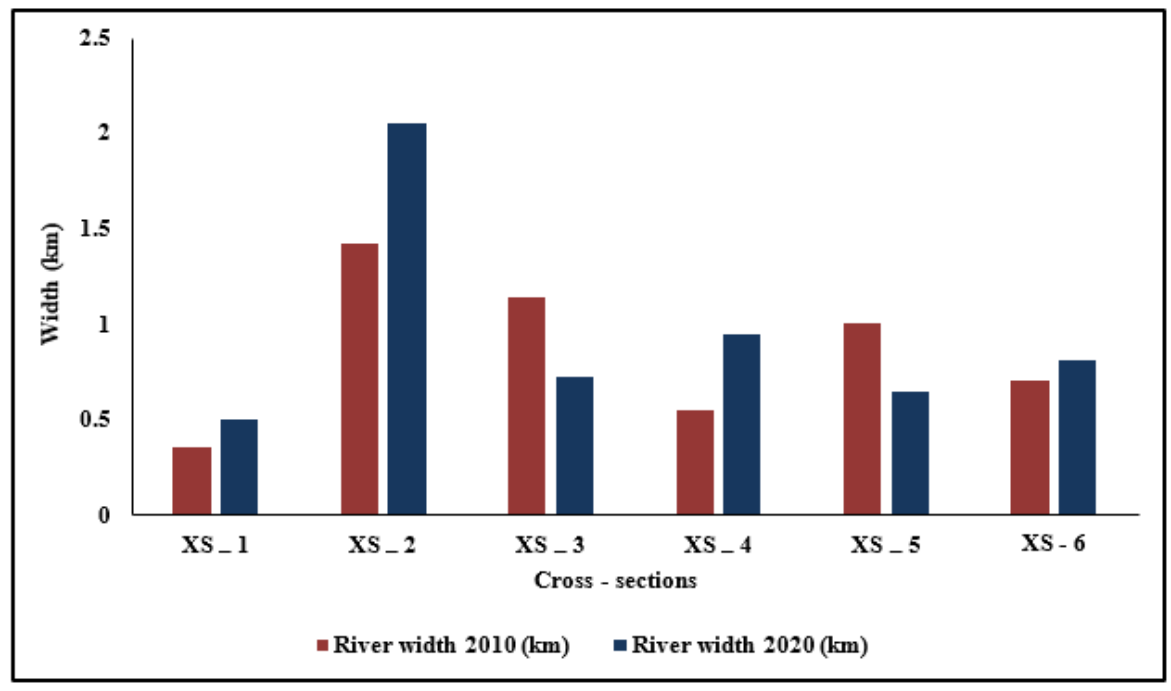

Figure 14: channel width variation from 2010 to 2020

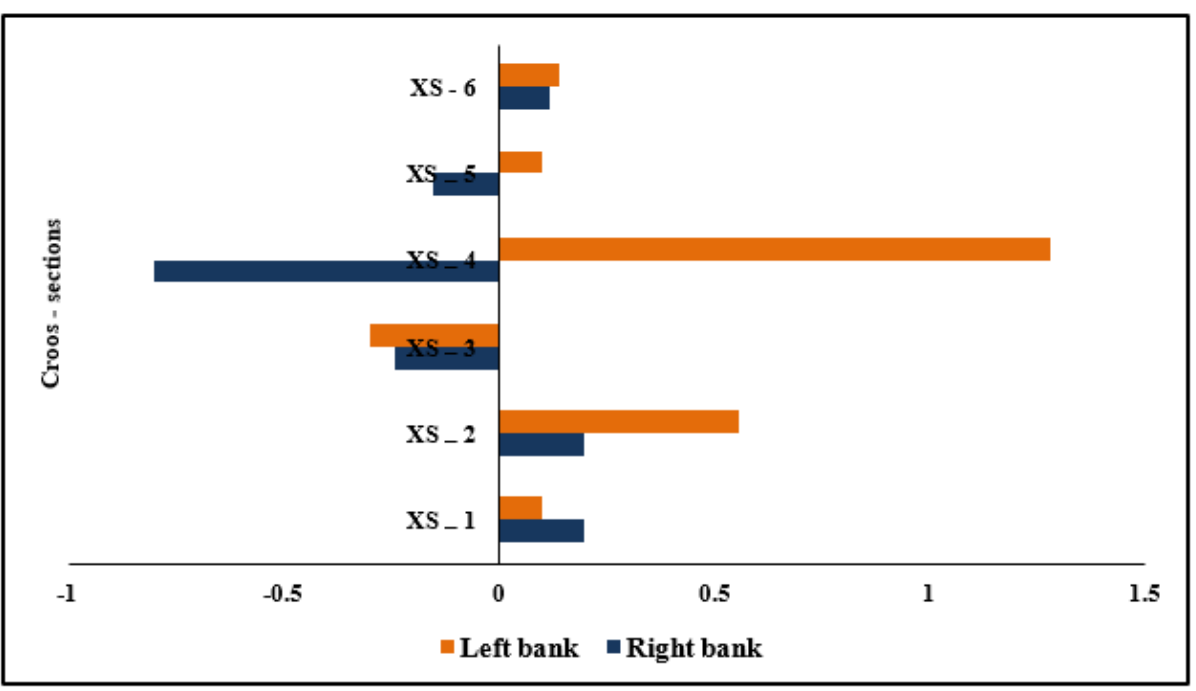

Figure 15: River Course Shifting line from 2000 to 2010

\subsection{Shifting Pattern of the Ganga River Course from 1980 to 2020.}

The change in the bank line of the Ganga river from 1980 to 2020 and channel change is shown by the map (Fig. 16). It is thereby found that various factors are responsible to this shifing, such as hydrological, morphological components and their characteristics are accountable for channel shifted. In the cross-section XS - 1, the river channel width has been changed to the erosion position on the left bank line and erosion the bank line in 1980 in the right bank. Here in 1980, the river channel width was more spread than in 2020. Moderately, in cross-section XS - 2, the river channel width increased a large amount (from $0.60 \mathrm{~km}$ to $2.05 \mathrm{~km}$ increasing) in 2020 than in 1980 due to erosion and revealed that the areal spread of the river has increased, shifted bank line right and left bank. Comparatively, in cross-section XS - 3, the river channel width was decreased from 1980 to 2020 (from $0.84 \mathrm{~km}$ to $0.72 \mathrm{~km})$ and in this section, the river has migrated towards the right bank $(0.32 \mathrm{~km})$. 


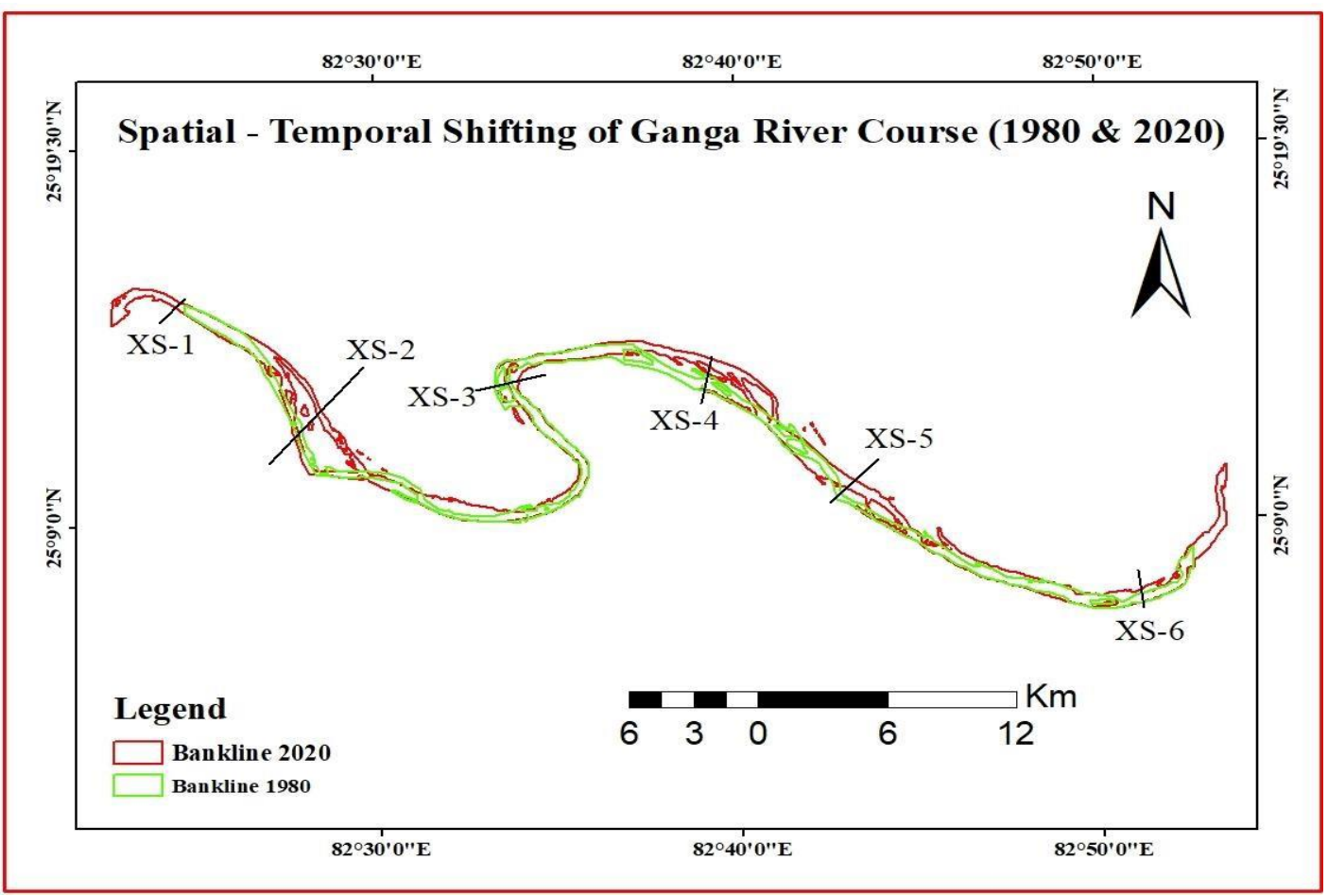

Figure 16: Apparent position of the River Ganga in the two-time zone and the cross-sections of calculating bank-line migration from 1980 to 2020

Table 5: Bank-line Migration Status along with the Cross-Sections from 1980 to 2020.

\begin{tabular}{|c|c|c|c|c|}
\hline Cross-section & River width $1980(\mathrm{~km})$ & River width $2020(\mathrm{~km})$ & Right bank & Left bank \\
\hline $\mathrm{XS}-1$ & 0.50 & 0.50 & 0.12 & 0.10 \\
\hline $\mathrm{XS}-2$ & 0.60 & 2.05 & 0.25 & 1.13 \\
\hline $\mathrm{XS}-3$ & 0.84 & 0.72 & 0.32 & -0.60 \\
\hline $\mathrm{XS}-4$ & 0.90 & 0.95 & 0.20 & 0.85 \\
\hline $\mathrm{XS}-5$ & 0.36 & 0.64 & -0.80 & 0.98 \\
\hline $\mathrm{XS}-6$ & 0.50 & 0.81 & 0.15 & 0.28 \\
\hline
\end{tabular}

The bank line has changed a small amount in 2020 in the cross-section XS - 4 in compare to 1980. The channel width was wide due to erosion on both sides to increase the right bank $(0.20 \mathrm{~km})$ and the left bank $(0.85 \mathrm{~km})$. In 'cross_section' XS - 5, that means in 1980, the river channel width has been narrow bank line course. But in 2020 the river channels have varied to erosion position on the left bank $(0.98 \mathrm{~km})$.

The width of river channel has been increased to $0.36 \mathrm{~km}$ in 2000 and that channel width has been $0.64 \mathrm{~km}$ in 2010 the 'cross-section' XS - 5, the river has shifted towards the left bank. In cross-section XS - 6, the river channel width has been increased as small in 2020 that channel width has been defined distance $0.50 \mathrm{~km}$ in 1980 and $0.81 \mathrm{~km}$ has been depicted in 2020 (Table 5)

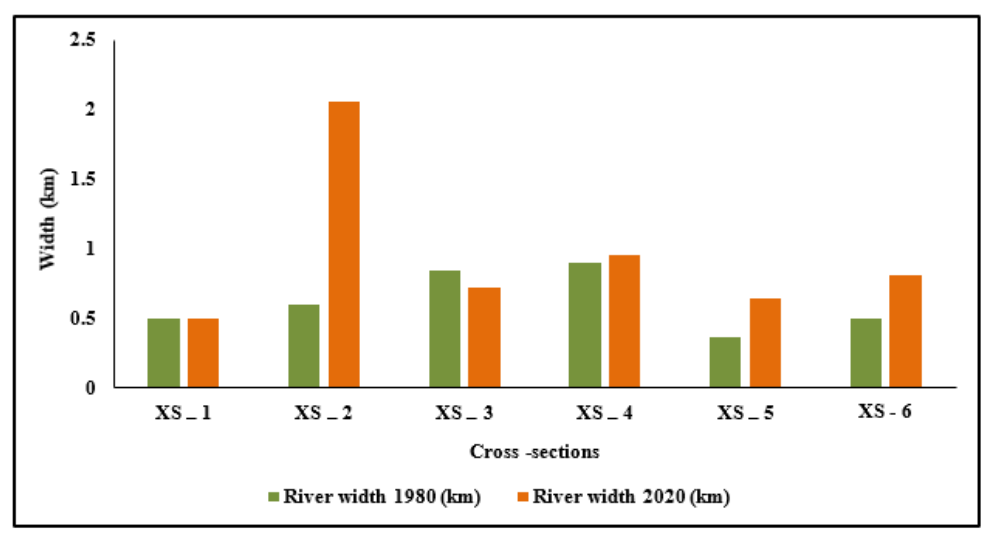

Figure 17: Channel width variation from 1980 to 2020 
'Cross-section' XS - 2, the river channel width has been represented as 0.60 in $1980 \mathrm{~km}$ and $2.05 \mathrm{~km}$ in 2010. In this segment it is the maximum channel width of the river. In cross-section XS - 1, the channel width increased a little amount on the left bank and the right bank has migrated towards the right bank Here, the river width shifting has been defined as $0.50 \mathrm{~km}$ distance in 1980, and the same distance has available in 2020 .

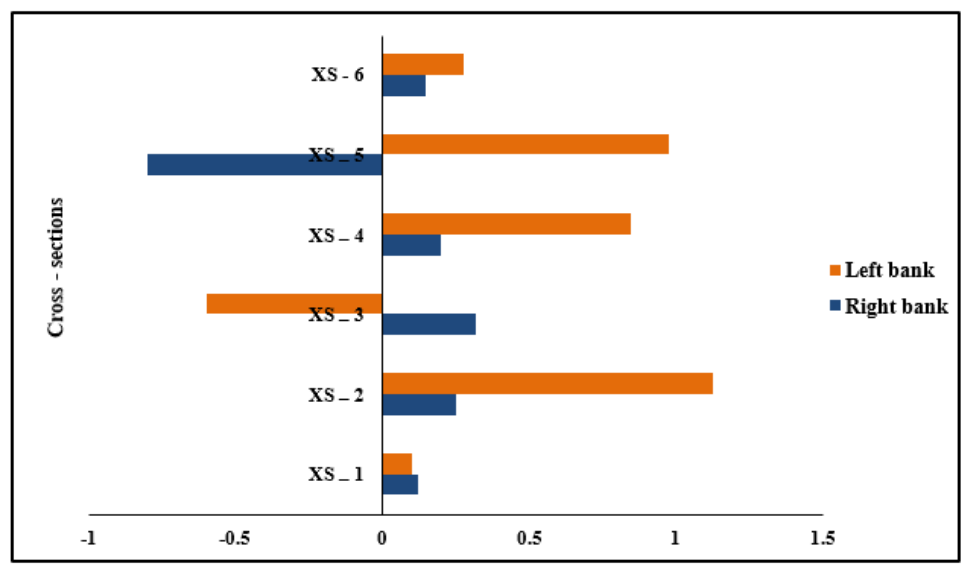

Figure 18: The changes of the left and right bank is gradually shifting bank line of the channel morphology from 1980 to 2010

All the cross-sections drawn along the courses of the river are used to calculate the bank-line migration status. How has the river shifted along with these fixed 6 the cross-sections is depicted in Tables 5. From the above maps, it can be stated that the river channel course line has been stepped up gradutally and resulting loss in land and water from the south-west to the north-east course. The study region of the change detection has been shifted bank lines on both sides (left and right) between 1980 to 2020 and from the northwest to the northeast course. Finally, in the cross-sections XS $-2 \&$ XS -4 the river width increased in both banks by erosion, and thereby, the river is witnessed a dramatic migration towards the left bank.

\section{Conclusion}

After examining the study, it is seen that after series of the Landsat satellite images were assembled and, thereby, found a historical changes in morphology in the study area and to provide the basis for a practical analysis of changing trend of the Ganga river. Therefore, this can be said that the erosion and deposition process is a common phenomenon of the river area including the Ganga River. It has been observed that hydrological and morphological processes, the river area has continuously been shifting its place, shape, outline and size. Flood and the bank line erosion since the significant time had developed one of the major parts of debate for its direct contact with the physical and socio-cultural background. It is revealed that the study region of the maximum channel was increased the width river in 2020, the Landsat satellite imagery. This study identified channel migration as vulnerable in cross-sections (XS - 1, 2, 3, 4, 5, and 6). Almost 6 cross-sections are recognized as highly vulnerable to channel shifting and need enough measurement construction for adjusting with the possible upcoming situation. The southwest to northeast flows and gradually changed the bank line shifting or missing point. Based on the idea of projected channel shifting development relating to limiting migration, recognizing place correctness for settlement, the setup could be calculated for more than 250 years in the Ganga river and surrounding environment in the present study area. The channel flow has gradually decreased to the old line as the Rampur Ghats had started to flow the Chunar place as a direct impact of it. Thus, the detection of course change has been found in the Ganga river between the period of 1980 to 2020 shown through the uses of satellite driven datas to demonstrate the visibility of shifting in its course.

\section{References}

Thakur, P. K., Laha, C., \& Aggarwal, S. P. (2012). River bank erosion hazard study of river Ganga, upstream of Farakka barrage using remote sensing and GIS. Natural Hazards, 61(3), 967-987.

Carling, P. A. (1988). Channel change and sediment transport in regulated UK rivers. Regulated Rivers: Research \& Management, 2(3), 369-387. 
Yadav, S. K., Singh, S. K., Gupta, M., \& Srivastava, P. K. (2014). Morphometric analysis of Upper Tons basin from Northern Foreland of Peninsular India using CARTOSAT satellite and GIS. Geocarto International, 29(8), 895914.

Nigam, M. K., Katiyar, S. K., \& Mittal, S. K. (2016). Change detection in course of River Ganga near Kanpur using remote sensing \& GIS techniques. IJ ScI. Eng. Res, 7(7), 762-765.

Langat, P. K., Kumar, L., \& Koech, R. (2019). Monitoring river channel dynamics using remote sensing and GIS techniques. Geomorphology, 325, 92-102.

Ety, N. J., \& Rashid, M. S. (2017). Changing pattern of the downstream of Ganges River Course: a comparison with Rennell's map of 1760s. Into J Sci Res Pub, 7(4), 90-105.

Mukherjee, K., \& Pal, S. (2018). Channel migration zone mapping of the River Ganga in the Diara surrounding region of Eastern India. Environment, Development and Sustainability, 20(5), 2181-2203.

Hasnain, S. I., \& Thayyen, R. J. (1999). Discharge and suspended-sediment concentration of meltwaters, draining from the Dokriani glacier, Garhwal Himalaya, India. Journal of Hydrology, 218(3-4), 191-198.

Gupta, N. (2012). Channel planform dynamics of the Ganga-Padma system, India (Doctoral dissertation, University of Southampton). 